\title{
A RECORD OF THE PIPE-VINE SWALLOWTAIL BUTTERFLY, BATTUS PHILENOR, FROM MANITOBA
}

\author{
by John H. Masters, Box 7511, St. Paul, Minnesota
}

I have been recently examining and cataloguing the correspondence file of the late Shirley Brooks of Winnipeg who published the most current list of Manitoba butterflies (Canadian Entomologist, 1942, 54:31-36). One interesting discovery is the disclosure of an important addition to the Manitoba list contained in a letter from Mr. D. W. Morden of Killarney, Manitoba dated September 12, 1942.

Mr. Morden wrote as follows: "This morning while sitting in my office, Mrs. Morden was standing in the front door and she called to me that there was a lovely butterfly around the flowers in front of the hotel. I immediately went out and grabbed my net that was sitting close to the door and went after it, however it was shy and it flew across to the next block to some other flowers. I followed it and carefully crept up to where it was on a large Zinnia flower and I got it the first try in my net. In looking up Hollands Butterfly Book I found it was a Papilio philenor (Plate XLII-fig. 3 , page 314 ). I thought I would ask you if you know of this butterfly ever having been taken in Manitoba or as far north as this ..."

Mr. Brooks replied (in a letter dated September 16, 1942): “ . . So far, $P$. philenor has not been recorded from Manitoba but it is, of course, possible that one or more may have strayed into the province . . . I should very much like to see the specimen. Without seeing it I cannot give any opinion on it. The swallowtail family have great variations and it might be an aberration of one of our native species. . . "I cannot ascertain if Brooks ever examined this specimen or not, but I suspect he did as in a later letter to Jack Dennis of Birtle, Manitoba he mentions that he has added Papilio philenor to the Manitoba list. The date of capture (September 12) would seem to rule out any of the native Manitoba species all of which are single-brooded and fly in the early summer.

The normal range of Battus philenor Linnaeus (formerly placed in the genus Papilio) is the southeastern United States and Mexico. It ranges west to the edge of the Great Plains in Missouri and Arkansas, and central Missouri seems to be the normal northern limit. A single stray had been previously recorded from Butter-. field in southern Minnesota-over 500 miles south of the Killarney locality.

The G. Shirley Brooks collection and related documents are the property of the Manitoba Museum of Man and Nature in Winnipeg. I am indebted to Mr. W. Harvey Beck, Keeper of Collections, for allowing me access to them.

\section{NOTES ON THE OCCURRENCE OF THE BOG COPPER, LYCAENA EPIXANTHE, IN MANITOBA}

\author{
by John H. Masłers, Box 7511, St. Paul, Minnesota
}

\section{Lycaena epixanthe Boisduval \&} Leconte is a small butterfly (wingspan 3/4" to 1") with a purplishcopper gloss on the upper wings and a pale yellowish underside with a red band at the anal angle. It is similar in appearance to Lycaena dorcas Kirby and Lycaena helloides Boisduval with which it is easily confused. Lycaena epixanthe is very local in 


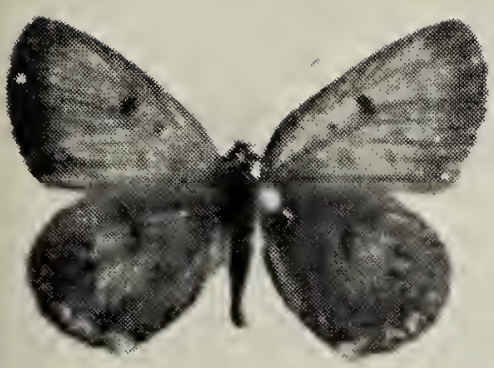

1

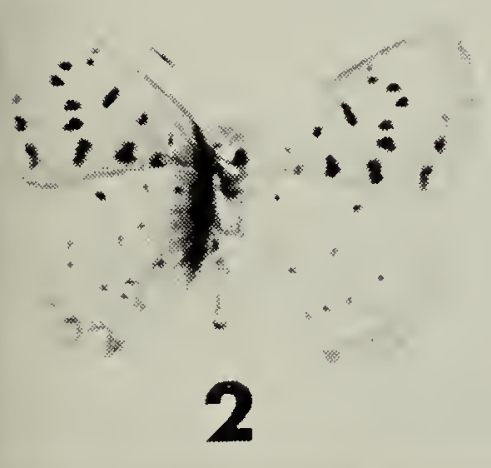

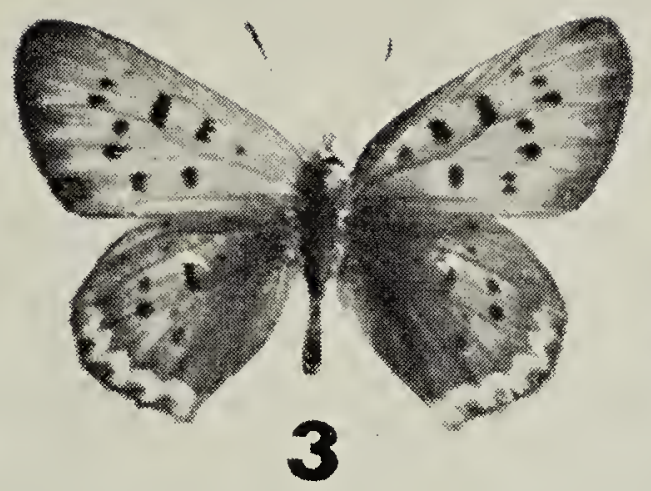

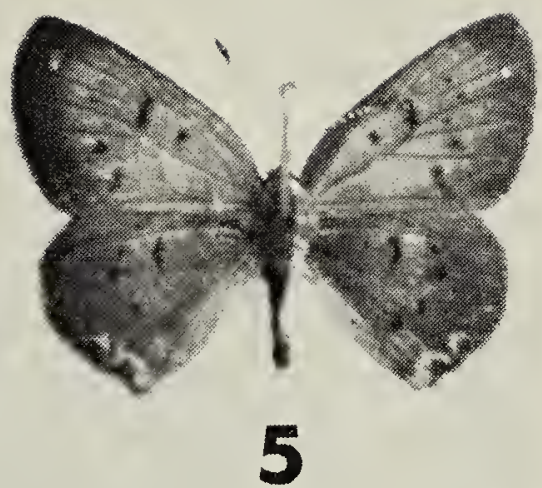

5

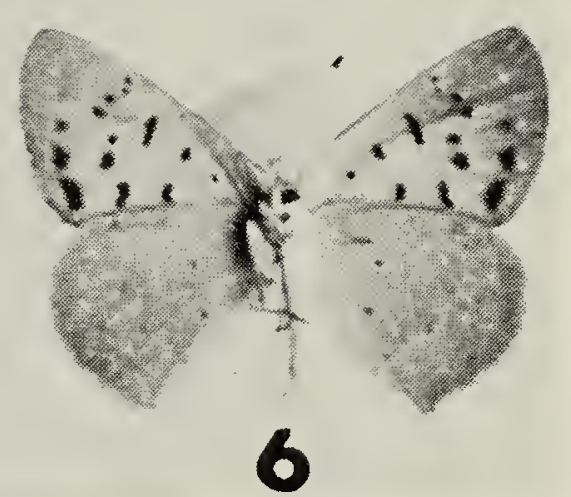

Figure 1, Lycaena epixanthe upper side; figure 2, L. epixanthe under side; figure 3, Lycaena helloides upper side; figure $4, L$. helloides under side; figure 5 , Lycaena dorcas upper side; figure $6, L$. dorcas under side. All figures are $1 \frac{1}{3}$ times natural size. All butterflies pictured are males.

habitat and never strays far away from its food plant, the small cranberry (Vaccinium oxycoccos L.), growing in acid sphagnum bogs.

The range of epixanthe is usually given as the Maritime Provinces and Quebec south to New Jersey and west to Ontario and Michigan and it was not included by Wallis (1921), Brodie (1929), or Brooks (1942), in their lists of Manitoba butterflies. The only published Manitoba record for epixanthe is by Bird (1956) who recorded collecting both Lycaena epixanthe and Lycaena dorcas in an open tamarack bog in the Whiteshell Forest Preserve of southeastern Manitoba. During August, 1967, however, I found epixanthe in several Manitoba bogs which extends its range across the southern half of the province to Riding Mountain. It is probably found in every southern Manitoba bog where its food plant, V. oxycoccos, grows and quite likely occurs in southeastern Saskatchewan as well. Epixanthe is single brooded and flies in late July and early August. It is fond of visiting flowers and is usually found on them at the edge of bogs.

There is one very old record of epixanthe in Manitoba by Heath (1899) who recorded it as L. helloides but added enough additional information that we are able to distinguish it as epixanthe. Mr. Heath, who lived at Cartwright, Manitoba, wrote: "I have a further addition to make of my list of the butterflies of Southern Manitoba, as a result of last summer's work. ... The scarcity of grass in the usual prairie hay meadows drove me into a small muskeg of a few acres in extent, in a corner of a river valley, about a mile from my house. ... In it, at the end of July and beginning of August, I took three or four specimens of Thecla acadica, and the same number of Lycaena thoe, and also a variety of $L$. helloides, smaller and more faintly marked than any I have taken before-the large form being generally abundant in certain places." Without a doubt, the 
small, faintly marked " $L$. helloides" represent $L$. epixanthe - a determination made 69 years later.

Lycaena hclloides is a western species that inhabits drier areas. Its food plants are dock (Rumex sp.) and knotweed (Polygonum sp.) and it is multiple brooded and can be found from June through September. The Purplish Copper, as it is commonly called, is somewhat larger than epixanthe (wingspan $1 \frac{1 / 4}{4}$ to $1 \frac{1}{2}$ inches) and it is quite a bit darker, especially on the under side where it is a dark rich orange instead of pale yellow.

The Dorcas Copper is intermediate in size between epixanthe and helloides (wingspan 1 to $1 \frac{1}{4}$ inches). It is very similar in appearance to the other two except that the hind wing beneath is a very dark, almost gray color. There is a single brood per year and in Manitoba it flies in early and midJuly. The food plant in New Brunswick is Shrubby Cinquefoil (Potentilla fruticosa L.), but it must be some other plant in Manitoba where the butterfly is most commonly found in marsh or grassy bog environments.

\section{LITERATURE CITED}

Bird, C. D. 1956. A collection of Rhopalocera from the Whiteshell Forest Reserve, Manitoba. Lepidopterists' News, 10:107-108.

Brodie, H. J. 1929. A preliminary list of the Lepidoptera of Manitoba. Trans. Royal Canadian Inst., $17: 81-101$.

Brooks, G. S. 1942. A checklist of the butterflies of Manitoba. Canadian Ent., $74: 31-36$.

Heath, E. F. 1899. Manitoba butterflies. Canadian Ent., 31:95.

Wallis, J. B. 1921. A colour key to the Manitoban butterflies. Nat. Hist. Soc. Manitoba Publ.

\section{Junior Naturalists}

\section{Edited by Joyce Deutscher, 7200 6th Ave., Regina}

\section{GOOD WORK JUNIORS}

Juniors have been busy writing newsy and interesting reports of their activities. Some of these are being held over for publication in the next newsletter.

Some of you may be still wondering what the newsletter is. One indignant young lady on being informed that her letter was published in the newsletter wrote back and said, "What newsletter?"

If you pick up your Blue Jay at the newsstand you may not be aware that for the same price you pay for four issues of the Blue Jay you can also get the Saskatchewan Natural History Society's newsletter and a membership in that society but you have to send your membership in to the society. The details are given on the back cover of each Blue Jay.

Letters from Juniors should be sent to Mrs. Joyce Deutscher, 7200-6th Ave., Regina for inclusion in the Junior Naturalist's Section.

\section{NATURE HOBBIES}

\section{by Helene R. White}

Note: This letter is a continuation of the one published in the newsletter wherein Mrs.
White tells about collecting goldenrod galls for hobby use. She promises more about this in a future letter.

Black-capped Chickadees followed me closely on this stroll along the banks of the wandering Waskesiu, for these little friends dine regularly at our homemade feeders in our garden. A simple feeder to construct merely requires a half gallon plastic bleach bottle, scissors, pencil, adhesive tape and some strong string or insulated wire. Thoroughly wash the container, keep the top and replace it, now take your pencil and mark the opening as shown. Holding the bottle under the hot water tap (heat makes cutting easier) cut this window out. Dry bottle thoroughly and place the adhesive tape over the sharp lower edge. The illustrations show you where to punch the holes for mounting. Thread the insulated wire or string through these holes.

Fill your feeder with commercial wild birdseed and a bit of bird gravel or sand for grit. Chickadees are very fond of chopped walnuts, uncooked and unsalted sunflower seeds and peanuts.

Now decide where you want it, face 